\title{
Screening of Promising Chemotherapeutic Candidates from Plants against Human Adult T-Cell Leukemia/Lymphoma (VII): Active Principles from Thuja occidentalis L.
}

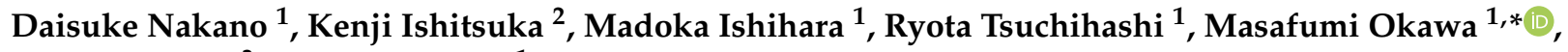 \\ Kazuo Tamura ${ }^{3}$ and Junei Kinjo ${ }^{1}$ \\ 1 Faculty of Pharmaceutical Sciences, Fukuoka University, Fukuoka 814-0180, Japan; \\ dnakano@fukuoka-u.ac.jp (D.N.); pp110077fu@gmail.com (M.I.); ryouta-t@fukuoka-u.ac.jp (R.T.); \\ kinjojun@fukuoka-u.ac.jp (J.K.) \\ 2 Division of Hematology and Rheumatology, Graduate School of Medical and Dental Sciences, \\ Kagoshima University, Kagoshima 890-8544, Japan; kenji-i@m.kufm.kagoshima-u.ac.jp \\ 3 Division of Medical Oncology, Hematology and Infectious Disease, Department of Internal Medicine, \\ Fukuoka University, Fukuoka 814-0180, Japan; ktamura@fukuoka-u.ac.jp \\ * Correspondence: mokawa@fukuoka-u.ac.jp
}

check for

updates

Citation: Nakano, D.; Ishitsuka, K.; Ishihara, M.; Tsuchihashi, R.; Okawa, M.; Tamura, K.; Kinjo, J. Screening of Promising Chemotherapeutic Candidates from Plants against Human Adult T-Cell Leukemia/ Lymphoma (VII): Active Principles from Thuja occidentalis L. Molecules 2021, 26, 7619. https://doi.org/ $10.3390 /$ molecules 26247619

\section{Academic Editors: Ana}

Estévez-Braun, Raju Aedla,

\section{Takashi Watanabe, Visweswara}

Rao Pasupuleti, Mikako Fujita and Yukio Nagano

Received: 18 November 2021 Accepted: 13 December 2021 Published: 15 December 2021

Publisher's Note: MDPI stays neutral with regard to jurisdictional claims in published maps and institutional affiliations.

Copyright: (c) 2021 by the authors. Licensee MDPI, Basel, Switzerland. This article is an open access article distributed under the terms and conditions of the Creative Commons Attribution (CC BY) license (https:// creativecommons.org/licenses/by/ $4.0 /)$.

\begin{abstract}
During the screening of novel chemotherapeutic candidates from plants against adult T-cell leukemia/lymphoma, we identified that the extracts of Thuja occidentalis (Cupressaceae) showed potent anti-proliferative activity in MT-1 and MT-2 cells. Therefore, we attempted to isolate the active components from this plant. We isolated and identified 32 compounds (1-32; eight lignans, 18 terpenoids, and six flavonoids) from the extracts of the leaves and cones. Their structures were determined by spectroscopic analysis. Several of the isolated compounds inhibited the growth of both cell lines. Lignans showed more potent activity than other classes of compounds. A comparison of the activities of compounds 1-8 revealed that the presence of a trans-lactone (linkage of C-6 to C-7) correlated with increased activity. Diterpenes showed moderate activity, and the presence of a ketone moiety at the C-7 position correlated with increased activity in compounds 12-21. In addition, biflavones showed moderate activity, and the presence of methoxy functions appeared to influence the activity of these compounds. Several lignans were lead compound of anti-cancer reagent (etoposide). In conclusion, not only lignans, but also diterpenes and/or biflavones, may be promising candidates for the treatment of adult T-cell leukemia/lymphoma.
\end{abstract}

Keywords: screening; adult T-cell leukemia/lymphoma; Thuja occidentalis

\section{Introduction}

Adult T-cell leukemia/lymphoma (ATL) is a malignancy of mature peripheral Tlymphocytes associated with human T-cell lymphotropic virus type I (HTLV-1). Conventional chemotherapeutic regimens used to treat other types of malignant lymphoma have been administered to ATL patients, but the therapeutic outcomes of acute- and lymphoma-type ATL remain very poor [1]. Therefore, we conducted a search for novel chemotherapeutic candidates for the treatment of ATL in plant extracts and tested these compounds in two cell lines. MT-1 cells were established from the peripheral blood tumor cells of ATL patients [2], and MT-2 cells were established from cord blood T-cells by cocultivation of normal human cord lymphocytes and peripheral blood tumor cells from an ATL patient [3].

We previously reported the screening of 582 extracts and the isolation of active constituents (withanolides, cardenolides, aporphine alkaloids, phenanthroindolizidine alkaloids, quinolone alkaloids, and coumarins) for testing in MT-1 and MT-2 cell lines [4-10]. In a previous paper, induction of apoptosis by 24,25 -dihydrowithanolide $\mathrm{D}$ determined by 
cytometric APO2.7-PC5 assay and evidenced by PARP cleavage [6], calotropin (cardenolide) induced apoptosis in MT-1 and MT-2 cells in a concentration-dependent manner, and the cell cycle experiments demonstrated that calotropin arrested MT- 1 and MT- 2 cells at the G2/M phase [7], accumulation of Sub-G1 cells were observed in MT-1 and MT-2 cells treated by liriodenine (aporphine alkaloid), suggesting induction of apoptosis [8]. Herein, following the results of our previous screening program [5], we report the isolation of active compounds from Thuja occidentalis, a plant belonging to the family Cupressaceae. T. occidentalis is native to North America and widely cultivated as ornamental tree known as white cedar [11]. Previous phytochemical studies on T. occidentalis have resulted in the isolation of several diterpenes (dehydroabietane, neothujic acids III and IV), lignans [(-)-matairesinol, $(-)$-thujaplicatin methyl ether, (-)-wikstromol, epi-pinoresinol], monoterpenes ( $\alpha$-thujone, $\beta$-thujone, fenchone), and a sesquiterpene alcohol [(+)-occidentalol] [12]. In traditional medicine, T. occidentalis has been used in the treatment of liver diseases, bronchitis, psoriasis, enuresis, amenorrhea, cystitis, uterine carcinomas, diarrhea, and rheumatism [13]. Thujone exerts proapoptotic and antiinvasive effects on GBM cells. They confirm the potential of $\alpha$-thujone for the treatment of glioblastoma multiforme [14]. In in vivo studies, $\alpha / \beta$-thujone promotes the regression of neoplasia and inhibited the angiogenic markers (VEGF, Ang-4, and CD31) into the tumor [15]. The aqueous extract and the polysaccharide fraction of T. occidentalis reduced production of proinflammatory cytokines (TNF- $\alpha$ and IL-6), decreased immunostaining of COX-2 and iNOS, and inhibited oxidative stress [16].

\section{Results and Discussion}

\subsection{Screening of Antiproliferative Activities of Cupressaceae Plants against MT-1 and MT-2 Cells}

Table 1 summarizes the anti-proliferative activities of several Cupressaceae plant extracts based on their activity in MT-1 and MT-2 cells. Despite variation in potency, anti-proliferative activity was exhibited by nine of the 10 extracts. In a preliminary test, the most potent anti-proliferative activity in MT- 1 and MT- 2 cells was exhibited by leaf extract following by the cone extract of T. occidentalis; therefore, we attempted to isolate the active compounds from these extracts. In addition, we attempted to isolate an extract from the cones of T. occidentalis.

Table 1. Anti-proliferative activities of the tested plant extracts.

\begin{tabular}{|c|c|c|c|c|}
\hline \multirow{2}{*}{ Family } & \multirow{2}{*}{ Scientific Name } & \multirow{2}{*}{ Parts } & \multicolumn{2}{|c|}{$\mathrm{EC}_{50}(\mu \mathrm{g} / \mathrm{mL})$} \\
\hline & & & MT-1 & MT-2 \\
\hline \multirow[t]{10}{*}{ Cupressaceae } & Biota orientalis & Leaves & $>100$ & $>100$ \\
\hline & & Stems & $>100$ & $>100$ \\
\hline & Juniperus chinensis var. kaizuka Hort & Leaves & 43.4 & 61.1 \\
\hline & & Stems & 18.1 & 10.8 \\
\hline & Juniperus rigida & Leaves & 14.0 & 13.2 \\
\hline & & Stems & $>100$ & $>100$ \\
\hline & Thuja occidentalis & Leaves & 1.65 & 1.38 \\
\hline & & Stems & 5.51 & 4.21 \\
\hline & & Cones & 1.74 & 0.50 \\
\hline & Thujopsis dolabrata & Aerial parts & 2.40 & 0.76 \\
\hline
\end{tabular}

The presented data are the mean of three independent experiments.

\subsection{Isolation of Compounds from the Extracts of T. occidentalis}

Extraction of the leaves of T. occidentalis was performed with $\mathrm{MeOH}$ under reflux, and the extract was initially partitioned between $n$-hexane and $80 \% \mathrm{MeOH}$. The $n$-hexane layer and $80 \% \mathrm{MeOH}$ layer were subjected to columns to isolate the compounds. Conversely, extraction of the cones of T. occidentalis was performed with $\mathrm{MeOH}$ under reflux and the extracts were subjected to columns to isolate the compounds.

The extracts were subjected to several chromatographic purification steps to obtain compounds 3-9, 11-18, 20-27, and 29-32 from the leaves; compounds 1-3, 6, 9-10, 19-20, and 27-29 were extracted from the cones (Figure 1). Compounds 1-32 had been previ- 
ously identified and the physical data of these compounds are in accordance to those reported [17-40].

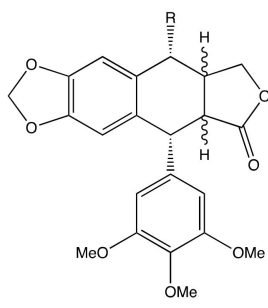

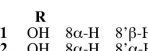

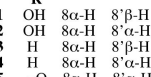<smiles>[2H][C@@]1(C)C(=O)OC[C@H]1Cc1ccc2c(c1)OCO2</smiles><smiles>COc1cccc(OC)c1OC</smiles>

$\begin{array}{cc} & \mathrm{R} \\ \mathbf{6} & \mathrm{H} \\ 7 & \mathrm{OH} \\ 8 & \mathrm{OA}\end{array}$<smiles>CC(=O)C1CCC2C1[C@@H](C(C)C)CC[C@]2(C)O</smiles><smiles>CC(C)C1=CC[C@@]2(C)C(C1)[C@@](C)(O)CC[C@H]2O</smiles>

Ho<smiles>CC(=CCO)CCCC(C)CCCC(C)CCCC(C)C</smiles><smiles>C=C[C@]1(C)CCC2C(C1)[C@H](C)CC1C(C)(C)CCCC21C</smiles>

"'il/,

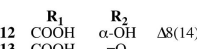

$\begin{array}{ll}13 \\ 14 \\ \mathrm{COOH} & \mathrm{COOH} \\ \mathrm{H} & \Delta 7\end{array}$

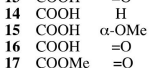<smiles>CC(C)c1cc2c(cc1Br)[C@@]1(C)CCCC(C)(C)[C@H]1C[C@@H]2C</smiles>

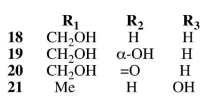<smiles>C=CC1=CCC2C(=C1)CCC1C(C)(O)CCCC21C</smiles>

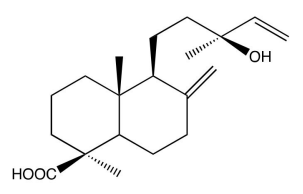

24<smiles>[R9]c1ccc(-c2cc(=O)c3c(O)cc(Br)c(-c4cc(-c5cc(=O)c6c(O)cc(C)cc6o5)ccc4[2H])c3o2)cc1</smiles><smiles>CC[C@H](CC[C@@H](C)C1CCC2[C@]3(C)CC=C4C[C@@H](O)CC[C@]4(C)C3CC[C@]12C)C(C)C</smiles><smiles></smiles>

Figure 1. Compounds from T. occidentalis.

\subsection{Determination of Anti-Proliferative Activity}

The anti-proliferative effects of compounds 1-32 are listed in Table 2. In addition, doxorubicin (clinically used antineoplastic drug) and etoposide (semisynthetic derivative of podophyllotoxin) were used as positive control. 
Table 2. Anti-proliferative activity of compounds 1-32, doxorubicin, and etoposide standards $\left(\mathrm{EC}_{50}\right)$.

\begin{tabular}{|c|c|c|}
\hline \multirow{2}{*}{ Compound } & \multicolumn{2}{|c|}{$\mathrm{EC}_{50}(\mu \mathrm{M})$} \\
\hline & MT-1 & MT-2 \\
\hline 1 & 0.115 & 0.134 \\
\hline 2 & 0.970 & 1.3 \\
\hline 3 & 0.0058 & 0.0033 \\
\hline 4 & 0.20 & 0.12 \\
\hline 5 & 43.7 & 16.5 \\
\hline 6 & 0.750 & 0.675 \\
\hline 7 & 9.46 & 7.98 \\
\hline 8 & 0.611 & 0.175 \\
\hline 9 & $>476$ & $>476$ \\
\hline 10 & 109 & 118 \\
\hline 11 & 63.9 & 125 \\
\hline 12 & 174 & 200 \\
\hline 13 & $>314$ & $>314$ \\
\hline 14 & 121 & 64.9 \\
\hline 15 & $>301$ & 172 \\
\hline 16 & 142 & 133 \\
\hline 17 & $>301$ & $>301$ \\
\hline 18 & 109.5 & 30.49 \\
\hline 19 & 25.8 & 19.2 \\
\hline 20 & 17.7 & 22.3 \\
\hline 21 & 103 & 125 \\
\hline 22 & 119 & 30.0 \\
\hline 23 & 74.6 & 140.9 \\
\hline 24 & 228 & 109 \\
\hline 25 & 88.1 & 135.8 \\
\hline 26 & 5.26 & 2.45 \\
\hline 27 & 7.07 & 5.78 \\
\hline 28 & $>172$ & $>172$ \\
\hline 29 & $>172$ & $>172$ \\
\hline 30 & 8.97 & 9.78 \\
\hline 31 & $>234$ & $>234$ \\
\hline 32 & $>169$ & $>169$ \\
\hline doxorubicin & 0.015 & 0.013 \\
\hline etoposide & 0.051 & 0.065 \\
\hline
\end{tabular}

Almost all of the isolated lignans (1-8) inhibited the growth of both tumor cell lines. But all compounds had weaker antiproliferative activity than positive control except compound 3 . The trans-lactone moiety in compounds $\mathbf{1}$ and $\mathbf{3}$ increased their anti-proliferative activity compared with compounds 2 and 4 , which do not possess a trans-lactone moiety. The presence of a hydroxyl group at position $7 \alpha$ in compounds $\mathbf{1}$ and $\mathbf{2}$ appeared to decrease the activity of these compounds compared with compounds 3 and 4 . Furthermore, the presence of a ketone moiety at position C-7 in compound 5 was associated with decreased activity in comparison to compound 4 , which lacked this moiety. Comparison of compounds 3 and 6 indicated that, the linkage of C-6 to C-7 appeared to enhance the activity (Figure 2).

Compared with compounds 6,7 , and 8 , the presence of substituents ( $\mathrm{OH}$ and $\mathrm{OAc})$ influenced the activities. 


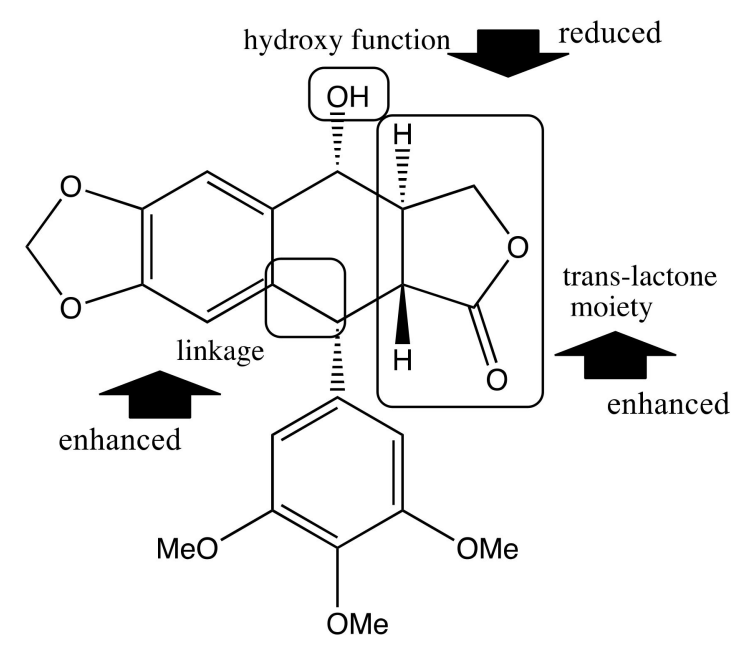

Figure 2. Structure-activity relationships of lignans.

Several of the isolated terpenoid compounds inhibited the proliferation of cell lines. The presence of a double bond at position C-8 in compound $\mathbf{1 6}$ appeared to enhance its activity compared with compound 13, which did not have a double bond at this position. Compared with compounds 15 and 16, the presence of a ketone moiety at position C-7 enhanced the activity. Similarly, compared with compounds 18, 19, and 20, the substituents (OH and ketone) influenced their activities (Figure 3).
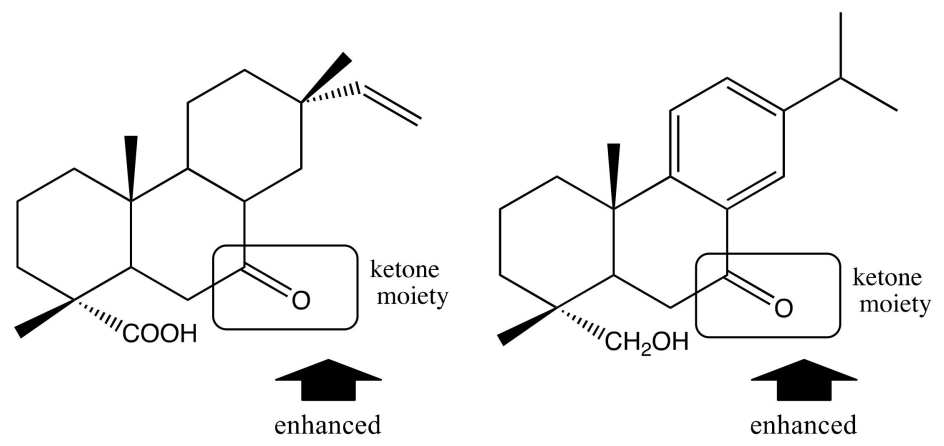

Figure 3. Structure-activity relationships of diterpenoids.

Several of the isolated flavonoids (25-30) inhibited the proliferation of cell lines. Comparison of compounds $25,26,27,28$, and 29, indicated the presence of one or two methoxy groups appeared to influence the activity of the compounds.

The $\mathrm{EC}_{50}$ value of compound 3 against MT- 1 and MT- 2 cell growth showed that compound 3 had the highest activity compared with the other compounds. Compounds 19 and 20 showed moderate activity in the current study. In previous studies, compound 19 showed cytotoxic activity in LOVO cells [32] and compound 20 showed cytotoxic activity in Hela cells and A549 cells [41]. In addition, both compounds have shown inhibition against Herpes Simplex Virus type 2 (HSV-2) [42]. Compounds 26 and $\mathbf{2 7}$ had moderate activity; these biflavones have shown anti-cancer properties in medulloblastoma, leukemia, osteosarcoma, colon, lung, neck, prostate, breast, cervical, ovarian, and kidney cancers [43]. Compound 27 inhibited the growth of Daoy and D283 cell lines, and induced G2/M cell cycle arrest in Daoy cells. Moreover, compound 27 reduced the expression of Wnt target genes, including Axin2 and cyclin D1, and inhibited the survival of MB cells [44].

\subsection{Apoptosis Analysis}

We analyzed the ability of the extracted compounds to induce apoptosis. The following experiments were studied for compound 3 which was the most active and compound 26 which was the most active except for lignans. Annexin V-positive cells were used to 
investigate the effects of deoxypodophyllotoxin (3) and isoginkgetin (26) on apoptosis. The proportion of annexin V-positive cells after the $72 \mathrm{~h}$ treatment with deoxypodophyllotoxin (3) and isoginkgetin (26) is shown in Figures 4 and 5, respectively. The distribution of apoptotic cells, which were located in the upper-right (late apoptotic/dead cells) and lower-right (early apoptotic cells) quadrants, was increased in cells treated with deoxypodophyllotoxin (3) and isoginkgetin (26). The concentration of deoxypodophyllotoxin (3) was changed $2 \mathrm{nM}$ to $10 \mathrm{nM}$ increased the early apoptotic cells from $23.20 \%$ to $70.32 \%$, the concentration of isoginkgetin (26) was changed $1.4 \mu \mathrm{M}$ to $35 \mu \mathrm{M}$ increased the early apoptotic cells from $24.35 \%$ to $55.35 \%$. In the case MT-2 had a similar tendency. Therefore, deoxypodophyllotoxin (3) and isoginkgetin (26) significantly induced apoptosis in MT-1 and MT-2 cells.

MT-1
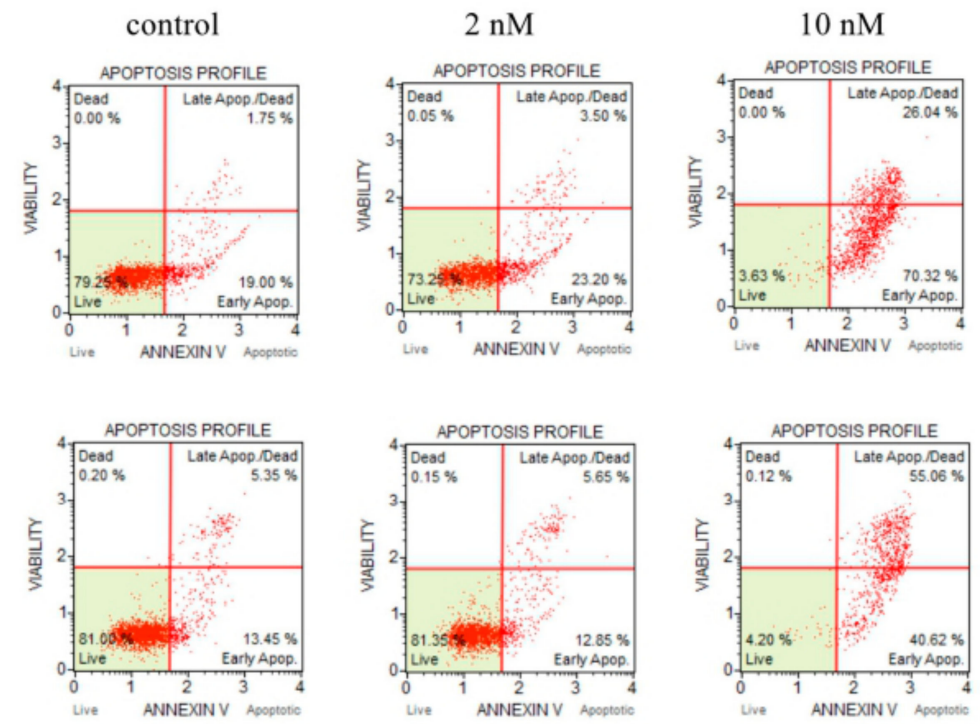

Figure 4. Deoxypodophyllotoxin (3) induced cell apoptosis in MT-1 and MT-2 cells.

MT-1

control
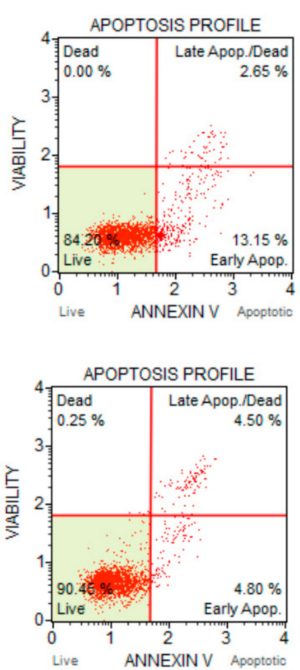

$1.4 \mu \mathrm{M}$
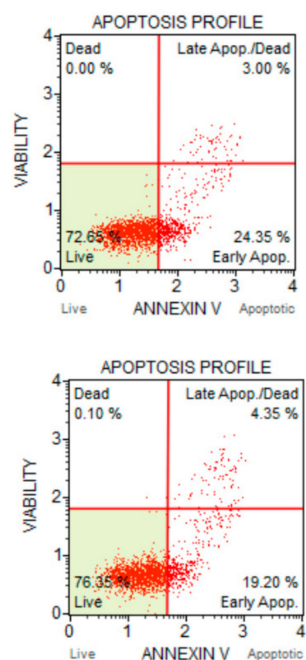

$35 \mu \mathrm{M}$
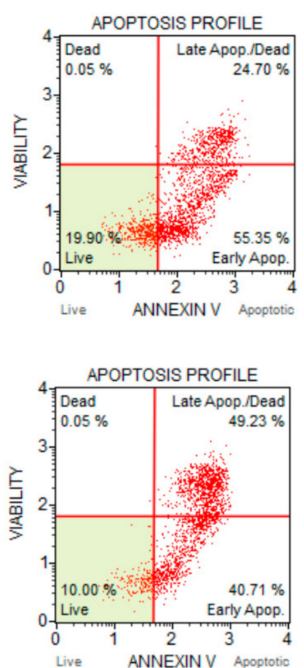

Figure 5. Isoginkgetin (26) induced cell apoptosis in MT-1 and MT-2 cells.

\section{Materials and Methods}

\subsection{General Experimental Procedures}

The ${ }^{1} \mathrm{H}-\mathrm{NMR}(600 \mathrm{MHz})$ and ${ }^{13} \mathrm{C}-\mathrm{NMR}(150 \mathrm{MHz})$ spectra were measured in $\mathrm{CDCl}_{3}$ or DMSO- $d_{6}$ using a JNM-ECZ600R spectrometer (JEOL, Tokyo, Japan) at room temperature, and the chemical shifts given as a $\delta$ (ppm) scale with tetramethylsilane (TMS) as the internal 
standard. The FAB-MS was measured using a JEOL JMS-HX110 mass spectrometer and acquired in a glycerol matrix. HPLC was conducted using a Waters machine equipped with a 1525 binary pump and a 2489 UV/Vis detector (Waters, Massachusetts, USA). Separation was carried out using a Cosmosil 5C 18 MS-II column $(20.0 \mathrm{~mm} \times 250 \mathrm{~mm}$, ODS, $5 \mu \mathrm{m}$; Nacalai Tesque, Kyoto, Japan). Apoptosis analyses were carried out using a Muse Cell Analyzer (Merck KGaA, Darmstadt, Germany).

\subsection{Plant Materials}

The plant materials used in this study were taken from the medicinal plant garden of Fukuoka University, located in Fukuoka, Japan. Voucher specimens were deposited in the Laboratory of Pharmacognosy of Fukuoka University, Fukuoka, Japan (FUN-0270).

\subsection{Extraction and Isolation}

The samples were powdered, and the compounds were extracted in accordance with the procedure described in a previous paper [4]. Extraction of the leaves of T. occidentalis (4860 g) was performed with $\mathrm{MeOH}$ under reflux. The extract (72.6 g) was initially partitioned using $n$-hexane and $80 \% \mathrm{MeOH}$. The $n$-hexane phase was subjected to a Diaion HP20 column using 85\% MeOH, 90\% MeOH, 95\% $\mathrm{MeOH}, 100 \% \mathrm{MeOH}$, and $\mathrm{MeOH}$ :acetone (4:1) to obtain fraction (fr.) LH1, LH2, LH3, LH4, and LH5, respectively. The fr. LH1 was subjected to a silica gel column using hexane:acetone (9:1) to obtain fr. LH1-1. The fr. LH1-1 was subjected to a silica gel column using hexane:EtOAc (3:1 and 2:1) to obtain fr. LH1-1-1 and compound 13 (1.9 mg). The fr. LH1-1-1 was subjected to HPLC purification using $55 \% \mathrm{MeCN}$ to obtain compound $17(22.0 \mathrm{mg})$. The fr. LH2 was subjected to a silica gel column using hexane:acetone (30:1, 10:1, and 5:1) to obtain fr. LH2-1, LH2-2, and LH2-3. The fr. LH2-1 was subjected to a silica gel column using hexane to obtain fr. LH2-1-1 and LH2-1-2. The fr. LH2-1-1 was subjected to a silica gel column using hexane:acetone (11:1) to obtain fr. LH2-1-1-1. The fr. LH2-1-1-1 was subjected to HPLC purification using 80\% $\mathrm{MeCN}$ to obtain compound 21 (13.2 $\mathrm{mg}$ ) and compound 22 (46.4 mg). The fr. LH2-1-2 was subjected to an ODS column using 60\% MeOH to obtain compound 14 (517.0 mg). The fr. LH2-2 was subjected to a silica gel column using hexane:acetone (10:1) to obtain fr. LH2-2-1. The fr. LH2-2-1 was subjected to HPLC purification using $90 \% \mathrm{MeCN}$ to obtain compound 15 (10.9 $\mathrm{mg})$. The fr. LH2-3 was subjected to a silica gel column using hexane:acetone (4:1 and 3:1) to obtain fr. LH2-3-1 and LH2-3-2, respectively. The fr. LH2-3-1 was subjected to a silica gel column using $\mathrm{CHCl}_{3}: \mathrm{MeOH}(30: 1)$ to obtain fr. LH2-3-1-1. The fr. LH2-3-1-1 was subjected to HPLC purification using $60 \% \mathrm{MeCN}$ to obtain compound 20 (20.5 mg). The fr. LH2-3-2 was subjected to a silica gel column using $\mathrm{CHCl}_{3}: \mathrm{MeOH}$ (25:1) to obtain fr. LH2-3-2-1. The fr. LH2-3-2-1 was subjected to HPLC purification using $50 \% \mathrm{MeCN}$ to obtain compound $16(18.0 \mathrm{mg})$. The fr. LH3 was subjected to a silica gel column using hexane:acetone (95:1) to obtain fr. LH3-1. The fr. LH3-1 was subjected to HPLC purification using $80 \% \mathrm{MeCN}$ to obtain compound 18 (19.8 mg). The fr. LH4 was subjected to a silica gel column using hexane:EtOAC (10:1) and $\mathrm{CHCl}_{3}: \mathrm{MeOH}: \mathrm{H}_{2} \mathrm{O}$ (17:3:0.3) to obtain fr. LH4-1 and LH4-2, respectively. The fr. LH4-1 was subjected to a silica gel column using hexane:acetone (50:1) to obtain fr. LH4-1-1. The fr. LH4-1-1 was subjected to HPLC purification using 85\% MeCN to obtain compound 11 (13.6 mg). The fr. LH4-2 was subjected to a silica gel column using acetone to obtain compound $32(18.0 \mathrm{mg})$. The fr. LH5 was subjected to a silica gel column using hexane:EtOAc (5:1) to obtain fr. LH5-1. The fr. LH5-1 was subjected to a silica gel column using hexane:acetone (10:1) to obtain fr. LH5-1-1. The fr. LH5-1-1 was subjected to HPLC purification using MeOH to obtain compound 31 (26.3 mg).

The $80 \% \mathrm{MeOH}$ phase was subjected to a Diaion HP-20 column using $\mathrm{MeOH}, \mathrm{MeOH}$ : acetone (3:2), and acetone to obtain fr. LM1, LM2, LM3, and LM4. The fr. LM1 was subjected to an MCI gel column using $80 \% \mathrm{MeOH}, 90 \% \mathrm{MeOH}$, and acetone to obtain fr. LM1-1, LM1-2, and LM1-3, respectively. The fr. LM1-1 was subjected to a silica gel column using hexane:acetone (5:1) to obtain fr. LM1-1-1. The fr. LM1-1-1 was subjected to 
a silica gel column using hexane:EtOAc (2:1) to obtain fr. LM1-1-1-1. The fr. LM1-1-1-1 was subjected to a silica gel column using $\mathrm{CHCl}_{3}: \mathrm{MeOH}(100: 1)$ to obtain fr. LM1-1-1-1-1. The fr. LM1-1-1-1-1 was subjected to HPLC purification using 40\% MeCN to obtain compound 9 (2.5 mg). The fr. LM1-2 was subjected to a silica gel column using hexane:acetone $(6: 1$, 5:1, 3:1, 2:1, and acetone) to obtain fr. LM1-2-1, LM1-2-2, LM1-2-3, LM1-2-4, and LM1-2-5, respectively. The fr. LM1-2-1 was subjected to a silica gel column using $\mathrm{CHCl}_{3}: \mathrm{MeOH}(84: 1)$ to obtain compound $24(6.2 \mathrm{mg})$. The fr. LM1-2-2 was subjected to a silica gel column using hexane:acetone (13:2) to obtain fr. LM1-2-2-1. The fr. LM1-2-2-1 was subjected to an ODS column using 77\% MeOH to obtain compound $12(22.0 \mathrm{mg})$. The fr. LM1-2-3 was subjected to a silica gel column using $\mathrm{CHCl}_{3}$ and $\mathrm{CHCl}_{3}: \mathrm{MeOH}(100: 1)$ to obtain compound 7 (6.7 $\left.\mathrm{mg}\right)$ and fr. LM1-2-3-1, respectively. The fr. LM1-2-3-1 was subjected to HPLC purification using $50 \% \mathrm{MeCN}$ to obtain compound 8 (5.7 $\mathrm{mg})$. The fr. LM1-2-4 was subjected to a silica gel column using hexane:acetone (2:1) to obtain fr. LM1-2-4-1. The fr. LM1-2-4-1 was subjected to a silica gel column using $\mathrm{CHCl}_{3}$ to obtain fr. LM1-2-4-1-1. The fr. LM1-2-4-1-1 was subjected to HPLC purification using $40 \% \mathrm{MeCN}$ to obtain compound 23 (4.1 mg). The fr. LM1-2-5 was subjected to a silica gel column using $\mathrm{CHCl}_{3}: \mathrm{MeOH}: \mathrm{H}_{2} \mathrm{O}$ (9:1:0.1) to obtain fr. LM1-2-5-1. The fr. LM1-2-5-1 was subjected to an ODS column using 30\% MeCN to obtain compound 25 (9.2 mg). The fr. LM1-3 was subjected to HPLC purification using $50 \% \mathrm{MeCN}$ to obtain compound $27(45.7 \mathrm{mg})$ and compound 26 (6.5 mg). The fr. LM2 was subjected to a silica gel column using hexane:EtOAC (3:2) to obtain fr. LM2-1. The fr. LM2-1 was subjected to a silica gel column using hexane:acetone $(3: 1$ and $5: 2)$ to obtain compound 6 (23.9 mg), compound 3 (730 mg), and fr. LM2-1-1. The fr. LM2-1-1 was subjected to HPLC purification using 35\% MeCN to obtain compound $4(2.7 \mathrm{mg})$ and compound $5(4.3 \mathrm{mg})$. The fr. LM3 was subjected to a silica gel column using hexane:EtOAc (1:1) to obtain fr. LM3-1. The fr. LM3-1 was subjected to a silica gel column using $\mathrm{CHCl}_{3}: \mathrm{MeOH}(80: 1)$ to obtain fr. LM3-1-1. The fr. LM3-1-1 was subjected to HPLC purification using 50\% MeCN to obtain compound 29 (2.2 mg). The fr. LM4 was subjected to a silica gel column using $\mathrm{CHCl}_{3}: \mathrm{MeOH}(15: 1)$ to obtain fr. LM4-1. The fr. LM4-1 was subjected to HPLC purification using 45\% MeCN to obtain compound 30 (4.6 mg).

Extraction of the cones of T. occidentalis (688 g) was performed with $\mathrm{MeOH}$ under reflux. The extract (72.6 g) was subjected to a Diaion HP-20 column using $80 \% \mathrm{MeOH}, 100 \%$ $\mathrm{MeOH}$, and acetone to obtain fr. $\mathrm{C} 1, \mathrm{C} 2$, and $\mathrm{C} 3$, respectively. The fr. $\mathrm{C} 1$ was subjected to a silica gel column using $\mathrm{CHCl}_{3}: \mathrm{MeOH}: \mathrm{H}_{2} \mathrm{O}$ (9:1:0.1) to obtain fr. $\mathrm{C} 1-1$. The fr. $\mathrm{C} 1-1$ was subjected to a silica gel column using hexane:acetone $(8: 1,7: 1$, and 2:1) to obtain fr. C1-1-1, C-1-1-2, and C1-1-3, respectively. The fr. C1-1-1 was subjected to HPLC purification using $50 \% \mathrm{MeCN}$ to obtain compound 9 (3.2 mg). The fr. C1-1-2 was subjected to a silica gel column using $\mathrm{CHCl}_{3}: \mathrm{MeOH}(80: 1)$ to obtain fr. C1-1-2-1. The fr. C1-1-2-1 was subjected to HPLC purification using 50\% MeCN to obtain compound 10 (14.0 mg) and compound 19 (3.0 mg). The fr. C1-1-3 was subjected to a silica gel column using hexane:EtOAc (2:3) to obtain fr. C1-1-3-1. The fr. C1-1-3-1 was subjected to HPLC purification using 30\% MeCN to obtain compound $2(2.8 \mathrm{mg})$. The fr. $\mathrm{C} 2$ was subjected to a silica gel column using $\mathrm{CHCl}_{3}: \mathrm{MeOH}(20: 1)$ to obtain fr. C2-1. The fr. C2-1 was subjected to a silica gel column using hexane:acetone (8:1, 6:1, and 4:1) to obtain fr. C2-1-1, C2-1-2, and C2-1-3, respectively. The fr. C2-1-1 was subjected to a silica gel column using hexane:EtOAc (7:2) to obtain fr. C2-1-1-1. The fr. C2-1-1-1 was subjected to HPLC purification using $60 \% \mathrm{MeCN}$ to obtain compound 20 (9.2 mg). The fr. C2-1-2 was subjected to a silica gel column using $\mathrm{CHCl}_{3}: \mathrm{MeOH}(40: 1)$ to obtain fr. C2-1-2-1. The fr. C2-1-2-1 was subjected to HPLC purification using 55\% MeCN to obtain compound 1 (10.5 mg). The fr. C2-1-3 was subjected to a silica gel column using hexane:EtOAc (2:1) to obtain fr. C2-1-3-1. The fr. C2-1-3-1 was subjected to HPLC purification using $40 \% \mathrm{MeCN}$ to obtain compound 3 $(63.0 \mathrm{mg})$ and compound $6(16.2 \mathrm{mg})$. The fr. C3 was subjected to a silica gel column using hexane:EtOAc (1:1) to obtain fr. C3-1. The fr. C3-1 was subjected to a silica gel column using $\mathrm{CHCl}_{3}: \mathrm{MeOH}$ (25:1) to obtain fr. C3-1-1 and C3-1-2. The fr. C3-1-1 was subjected to HPLC purification using 60\% MeCN to obtain compound 29 (3.1 mg) and compound 28 
(2.0 mg). The fr. C3-1-2 was subjected to HPLC purification using $45 \% \mathrm{MeCN}$ to obtain compound 27 (5.3 mg).

\subsection{Identification of Compounds}

Compounds 1-32 were identified as podophyllotoxin (1) [17], picropodophyllotoxin (2) [17], deoxypodophyllotoxin (3) [18], deoxypicropodophyllotoxin (4) [19], picropodophyllone (5) [20], (-)-yatein (6) [21], podorhizol (7) [22], podorhizol acetate (8) [23], oplopanone (9) [24], oplodiol (10) [25], phytol (11) [26], 7 $\alpha$-hydroxysandaracopimaric acid (12) [18], 7-oxo-epi-pimara-15-en-18-oic acid (13) [27,28], isopimaric acid (14) [29], macrophypene C (15) [30], 7-oxo-epi-pimara-8,15-dien-19-oic acid (16) [28], 7-oxo-epi-pimara-15-ene-18oic acid methyl ester (17) [28], 4-epi-dehydroabietinol (18) [31], 8,11,13-abietatriene-7 $\alpha$, 18-diol (19) [32], 7-oxodehydroabietinol (20) [33], ferruginol (21) [34], (+)-totarol (22) [35], Ecommunic acid (23) [18], (+)-cupressic acid (24) [36], amentoflavone (25) [37], isoginkgetin (26) [37], ginkgetin (27) [37], 7, 4', 4'"-trimethyl-amentoflavone (28) [38], 7,4', $7^{\prime \prime}$ - trimethylamentoflavone (29) [38], hinokiflavone (30) [37], $\beta$-sitosterol (31) [39], and $\beta$-sitosterol glycoside (32) [40], respectively, based on the comparison of their physical data with those reported in the literature (Tables S1-S5).

\subsection{Cell Culture}

Two HTLV-1-infected T-cell lines, MT-1 and MT-2, were kindly provided by Dr Isao Miyoshi of Kochi University in Nankoku, Japan. Culture conditions were as previously described [5]. The cells were cultured in RPMI-1640 medium with L-glutamine and sodium bicarbonate containing $15 \%$ fetal bovine serum (Biowest, Nuaille, France) and 1\% kanamycin. Cells were cultured at $37^{\circ} \mathrm{C}$ in humidified $5 \% \mathrm{CO}_{2} / 95 \%$ air.

\subsection{Measurement of Anti-Proliferative Effects against MT-1 and MT-2 Cells}

Viability was determined using the MTT assay. The MT- 1 and MT- 2 cells were maintained in RPMI-1640 medium containing fetal bovine serum (15\%). A $50-\mu \mathrm{L}$ aliquot of the cell suspension (5000 cells per well) and $50 \mu \mathrm{L}$ of the test sample solution or suspension were plated in flat-bottomed microtiter wells (extract final concentration: 100, 10, 1, $0.1 \mu \mathrm{g} / \mathrm{mL}$, and control; compound final concentration: between $10 \mathrm{pg} / \mathrm{mL}$ and $100 \mu \mathrm{g} / \mathrm{mL}$, and control) and incubated for $72 \mathrm{~h}$ at $37^{\circ} \mathrm{C}$ in a humidified atmosphere containing $5 \%$ $\mathrm{CO}_{2}$. After cultivation, $10 \mu \mathrm{L}$ of 3-(4,5)-dimethyl-2-thiazoyl-2,5-diphenyl-2H-tetrazolium bromide (MTT reagent) solution was added to the microtiter wells. After incubation for $4 \mathrm{~h}$ at $37^{\circ} \mathrm{C}, 100 \mu \mathrm{L}$ of isopropanol was added to solubilize the MTT-formazan product. The absorbance at $450 \mathrm{~nm}$ was measured with a microplate reader.

\subsection{Apoptosis Analysis}

Detection of apoptosis was performed using The Muse Annexin V \& Dead Cell Assay Kit (Merck, Darmstadt, Germany) according to the manufacturer's protocol. MT-1 and MT-2 cells incubated in the presence or absence of compound 3 and 26 for $72 \mathrm{~h}$ were collected by centrifugation ( $310 \times \mathrm{g}$ at $4{ }^{\circ} \mathrm{C}$ for $10 \mathrm{~min}$ ), suspended in $100 \mu \mathrm{L}$ of RPMI 1640 medium, and incubated with $100 \mu \mathrm{L}$ of Annexin V reagent at room temperature for $20 \mathrm{~min}$. Cells were measured by a Muse Cell Analyzer (Merck, Darmstadt, Germany).

\section{Conclusions}

In conclusion, as part of our investigations of Cupressaceae plants, extracts of $T$. occidentalis showed potent inhibitory effects against MT-1 and MT-2 cell lines. We isolated 32 compounds (eight lignans, 18 terpenoids, and six flavonoids) from the extract and examined their structure-activity relationships. Almost all of the isolated lignans inhibited the growth of both tumor cell lines. Several diterpene compounds had moderate activity, of which some have been previously reported to exhibit cytotoxicity in cancer cells. Moreover, several flavonoids showed moderate activity; some of these biflavones have been reported to show anti-cancer properties in some cancers and may induce cell cycle arrest, and 
inhibitory activities against amyloid- $\beta$ peptide 42 cytotoxicity in PC-12 cells [45]. We continue to search the biflavone and components of other Cupressaceae plants. We also demonstrated that deoxypodophyllotoxin (3) and isoginkgetin (26) enhanced apoptosis. Therefore, not only lignans but also diterpenes and/or biflavones may be promising candidates for the treatment of ATL.

Supplementary Materials: The following are available online, contain ${ }^{13} \mathrm{C}-\mathrm{NMR}$ data of compounds (Table S1: ${ }^{13} \mathrm{C}-\mathrm{NMR}$ spectroscopic $\left(\mathrm{CDCl}_{3}\right)$ of compounds 1-8. Table S2: ${ }^{13} \mathrm{C}-\mathrm{NMR}$ spectroscopic $\left(\mathrm{CDCl}_{3}\right)$ of compounds 9-11. Table S3: ${ }^{13} \mathrm{C}-\mathrm{NMR}$ spectroscopic $\left(\mathrm{CDCl}_{3}\right)$ of compounds 12-24. Table S4: ${ }^{13} \mathrm{C}-\mathrm{NMR}$ spectroscopic (DMSO- $d_{6}$ ) of compounds $25-30$. Table S5: ${ }^{13} \mathrm{C}-\mathrm{NMR}$ spectroscopic $\left(\mathrm{CDCl}_{3}\right)$ of compounds 31 and 32.)

Author Contributions: Conceptualization, J.K., K.I. and K.T.; methodology, J.K. and D.N.; formal analysis, D.N., M.I. and R.T.; investigation, D.N. and M.I.; resources, M.O.; data curation, D.N. and M.I.; writing—original draft preparation, D.N.; writing—review and editing, J.K., M.O., R.T. and K.I.; visualization, D.N. and M.I.; supervision, J.K., M.O. and K.I.; project administration, J.K. All authors have read and agreed to the published version of the manuscript.

Funding: This work was supported by Japan Society for the Promotion of Science JSPS KAKENHI Grant Number JP19K16403.

Institutional Review Board Statement: Not applicable.

Informed Consent Statement: Not applicable.

Acknowledgments: We thank Georgia Lenihan-Geels, from Edanz (https:/ /jp.edanz.com/ac, last accessed on 15 December 2021) for editing a draft of this manuscript.

Conflicts of Interest: The authors declare no conflict of interest.

Sample Availability: Samples of the compounds are not available from the authors.

\section{References}

1. Ishitsuka, K.; Tamura, K. Treatment of adult T-cell leukemia/lymphoma: Past, present, and future. Eur. J. Haematol. 2008, 80, 185-196. [CrossRef] [PubMed]

2. Miyoshi, I.; Kubonishi, I.; Sumida, M.; Hiraki, S.; Tsubota, T.; Kimura, I.; Miyamoto, K.; Sato, J. A novel T-cell line derived from adult T-cell leukemia. GANN Jpn. J. Cancer Res. 1980, 71, 155-156.

3. Miyoshi, I.; Kubonishi, I.; Yoshimoto, S.; Akagi, T.; Ohtsuki, Y.; Shiraishi, Y.; Nagata, K.; Hinuma, Y. Type C virus particles in a cord T-cell line derived by cocultivating normal human cord leukocytes and human leukaemic T cells. Nature 1981, 294, 770-771. [CrossRef] [PubMed]

4. Kinjo, J.; Nakano, D.; Fujioka, T.; Okabe, H. Screening of promising chemotherapeutic candidates from plants extracts. J. Nat. Med. 2016, 70, 335-360. [CrossRef]

5. Nakano, D.; Ishitsuka, K.; Hatsuse, T.; Tsuchihashi, R.; Okawa, M.; Okabe, H.; Tamura, K.; Kinjo, J. Screening of promising chemotherapeutic candidates against human adult T-cell leukemia/lymphoma from plants: Active principles structure-activity relationships with withanolides. J. Nat. Med. 2011, 65, 559-567. [CrossRef]

6. Nakano, D.; Ishitsuka, K.; Katsuya, H.; Kunami, N.; Nogami, R.; Yoshimura, Y.; Matsuda, M.; Kamikawa, M.; Tsuchihashi, R.; Okawa, M.; et al. Screening of promising chemotherapeutic candidates from plants against human adult T-cell leukemia/lymphoma (II): Apoptosis of antiproliferactive principle (24,25-dihydrowithanolide D) against ATL cell lines and structure-activity relationships with withanolides isolated from solanaceous plants. J. Nat. Med. 2012, 66, 415-420.

7. Nakano, D.; Ishitsuka, K.; Takashima, M.; Arima, R.; Satou, A.; Tsuchihashi, R.; Okawa, M.T.; Tamura, K.; Kinjo, J. Screening of promising chemotherapeutic candidates from plants against human adult T-cell leukemia/lymphoma (VI): Cardenolides from Asclepias curassavica. Biol. Pharm. Bull. 2020, 43, 1609-1614. [CrossRef]

8. Nakano, D.; Ishitsuka, K.; Kamikawa, M.; Matsuda, M.; Tsuchihashi, R.; Okawa, M.; Okabe, H.; Tamura, K.; Kinjo, J. Screening of promising chemotherapeutic candidates from plants against human adult T-cell leukemia/lymphoma (III). J. Nat. Med. 2013, 67, 894-903. [CrossRef] [PubMed]

9. Nakano, D.; Ishitsuka, K.; Mizuki, I.; Tsuchihashi, R.; Okawa, M.; Okabe, H.; Tamura, K.; Kinjo, J. Screening of promising chemotherapeutic candidates from plants against human adult T-cell leukemia/lymphoma (IV): Phenanthroindolizidine alkaloids from Tylophora tanakae leaves. J. Nat. Med. 2015, 69, 397-401. [CrossRef]

10. Nakano, D.; Ishitsuka, K.; Matsuda, N.; Kouguchi, A.; Tsuchihashi, R.; Okawa, M.; Okabe, H.; Tamura, K.; Kinjo, J. Screening of promising chemotherapeutic candidates from plants against human adult T-cell leukemia/lymphoma (V): Coumarins and alkaloids from Boenninghausenia japonica and Ruta graveolens. J. Nat. Med. 2017, 71, 170-180. [CrossRef] 
11. Alves, L.D.S.; Figueiredo, C.B.M.; Silva, C.C.A.R.; Marques, G.S.; Ferreira, P.A.; Soares, M.F.R.; Silva, R.M.F.; Rolim-Neto, P.J. Thuja occidentalis L. (Cupressaceae): Review of botanical, phytochemical, pharmacological and toxicological aspects. Int. J. Pharm. Sci. Res. 2014, 5, 1163-1177.

12. Chang, L.C.; Song, L.L.; Park, E.J.; Luyengi, L.; Lee, K.J.; Farnsworth, N.R.; Pezzuto, J.M.; Kinghorn, A.D. Bioactive constituents of Thuja occidentalis. J. Nat. Prod. 2000, 63, 1235-1238. [CrossRef]

13. Sonia, C.; Alina, C.; Neli, K.O.; Ioan, D.; Anca, H.; Coralia, C. Thuja occidentalis L. (Cupressaceae): Ethnobotany, phytochemistry and biological activity. Molecules 2020, 25, 5416.

14. Pudełek, M.; Catapano, J.; Kochanowski, P.; Mrowiec, K.; Janik-Olchawa, N.; Czyz, J.; Ryszawy, D. Therapeutic potential of monoterpene $\alpha$-thujone, the main compound of Thuja occidentalis L. essential oil, against malignant glioblastoma multiforme cells in vitro. Fitoterapia 2019, 134, 172-181. [CrossRef]

15. Torres, A.; Vargas, Y.; Uribe, D.; Carrasco, C.; Torres, C.; Rocha, R.; Oyarzun, C.; Martin, R.S.; Quezada, C. Pro-apoptotic and anti-angiogenic properties of the $\alpha / \beta$-thujone fraction from Thuja occidentalis on glioblastoma cells. J. Neurooncol. 2016, 128, 9-19. [CrossRef] [PubMed]

16. Silva, I.S.; Nicolau, L.A.D.; Sousa, F.B.M.; de Araújo, S.; Oliveira, A.P.; Araújo, T.S.L.; Souza, L.K.M.; Martins, C.S.; Aquino, P.E.A.; Carvalho, L.L.; et al. Evaluation of anti-inflammatory potential of aqueous extract and polysaccharide fraction of Thuja occidentalis Linn. in mice. Int. J. Biol. Macromol. 2017, 105, 1105-1116. [CrossRef] [PubMed]

17. Zhao, L.; Tian, X.; Fan, P.C.; Zhan, Y.J.; Shen, D.W.; Jin, Y. Separation, determination and identification of the diastereoisomers of podophyllotoxin and its esters by high-performance liquid chromatography/tandem mass spectrometry. J. Chromatogr. A 2008, 1210, 168-177. [CrossRef]

18. Muto, N.; Tomokuni, T.; Haramoto, M.; Takemoto, H.; Nakanishi, T.; Inatomi, Y.; Murata, H.; Inada, A. Isolation of apoptosis- and differentiation- inducing substances toward human promyelocytic leukemia HL-60 cells from leaves of Juniperus taxifolia. Biosci. Biotechnol. Biochem. 2008, 72, 477-484. [CrossRef] [PubMed]

19. San Feliciano, A.; Medarde, M.; Lopes, J.L.; Puebla, P.; Miguel del Corral, J.M.; Barrero, A.F. Lignans from Juniperus thurifera. Phytochemistry 1989, 28, 2863-2866. [CrossRef]

20. Lei, M.; Hu, R.J.; Wang, Y.G. Mild and selective oxidation of alcohols to aldehydes and ketones using $\mathrm{NaIO}_{4} / \mathrm{TEMPO} / \mathrm{NaBr}$ system under acidic conditions. Tetrahedron 2006, 62, 8928-8932. [CrossRef]

21. Tomioka, K.; Ishiguro, T.; Koga, K. Stereoselective reactions. X. total synthesis of optically pure antitumor lignans, bursran. Chem. Pharm. Bull. 1985, 33, 4333-4337. [CrossRef]

22. Giordano, T.; Marcelo, F.A.; Fernando, C. Diastereoselective synthesis of b-piperonyl- $\gamma$-butyrolactones from morita-baylis-hillman adducts. Highly efficient synthesis of $( \pm)$-yatein, $( \pm)$-podorhizol and ( \pm )-epi-podorhizol. J. Braz. Chem. Soc. 2010, 21, 2327-2339.

23. San Feliciano, A.; Miguel del Corral, J.M.; Gordaliza, M.; Castro, A. Lignans from Juniperus sabina. Phytochemistry 1990, 29, 1335-1338. [CrossRef]

24. Su, W.C.; Fang, J.M.; Cheng, Y.S. Sesquiterpenes from leaves of Cryptomeria japonica. Phytochemistry 1995, 39, $603-607$.

25. Jung, K.Y.; Kim, D.S.; Oh, S.R.; Lee, I.S.; Lee, J.J.; Lee, H.K.; Shin, D.H.; Kim, E.H.; Cheong, C.J. Sesquiterpene components from the flower buds og Magnolia fargesii. Arch. Pharm. Res. 1997, 20, 363-367. [CrossRef]

26. Goodman, R.A.; Oldfield, E.; Allerhand, A. Assignments in the natural-abundance carbon-13 nuclear magnetic resonance spectrum of chlorophyll and a study of segmental motion in neat phytol. J. Am. Chem. Soc. 1973, 95, 7553-7558. [CrossRef]

27. Werner, H.; Palaniappan, K. Ent-pimaranes, ent-kauranes, heliangolides and other constituents of three Helianthus species. Phytochemistry 1984, 23, 1453-1459.

28. Urones, J.G.; Marcos, I.S.; Ferreras, J.F.; Barcala, P.B. Terpenoids from Nepta tuberosa subsp. Reticulata (II). Phytochemistry 1988, 27, 523-526. [CrossRef]

29. Sakar, M.K.; Er, N.; Ercil, D.; Olmo, E.D.; San Feliciano, A. (-)-Desoxypodophyllotoxin and diterpenoids from juniperus nana willd. berries. Acta. Pharm. Turc. 2002, 44, 213-219.

30. Xu, J.; Sun, Y.; Wang, M.; Ren, Q.; Li, S.; Wang, H.; Sun, X.; Jin, D.-Q.; Sun, H.; Ohizumi, Y.; et al. Bioactive diterpenoids from the leaves of Callicarpa macrophylla. J. Nat. Prod. 2015, 78, 1563-1569. [CrossRef]

31. Fraga, M.F.; Hernandez, M.G.; Artega, J.M.; Suarez, S. The microbiological transformation of the diterpenes dehydroabietanol and teideadiol by Mucor plumbeus. Phytochemistry 2003, 63, 663-668. [CrossRef]

32. Yang, X.W.; Feng, L.; Li, S.M.; Liu, X.H.; Li, Y.L.; Wu, L.; Shen, Y.H.; Tian, J.M.; Zhang, X.; Liu, X.R.; et al. Isolation, structure, and bioactivities of abiesadines A-Y, 25 new diterpenes from Abies georgei Orr. Bioorg. Med. Chem. 2010, 18, 744-754. [CrossRef]

33. Tanaka, R.; Ohtsu, H.; Matsunaga, S. Abietane diterpene acids and other constituents from the leaves of Larix kaempferi. Phytochemistry 1997, 46, 1051-1057. [CrossRef]

34. Ryu, Y.B.; Jeong, H.J.; Kim, J.H.; Kim, Y.M.; Park, J.Y.; Kim, D.; Naguyen, T.T.H.; Park, S.J.; Chang, J.S.; Park, K.H.; et al.

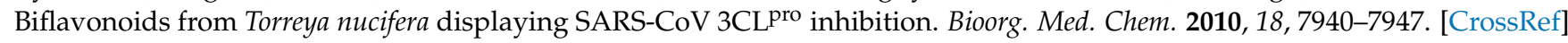
[PubMed]

35. Marcos, L.S.; Cubillo, M.A.; Moro, R.F.; Diez, D.; Basabe, P.; Sanz, F.; Urones, J.G. Synthesis of (+)-totarol. Tetrahedron Lett. 2003, 44, 8831-8835. [CrossRef]

36. Liu, C.M.; Zhou, H.B.; Zhang, W.D. terpenoids from stems and leaves of Cupressus gigantea. Chin. J. Nat. Med. 2010, 8, 405-410. [CrossRef] 
37. Markham, K.R.; Sheppard, C.; Geiger, H. ${ }^{13} \mathrm{C}$ NMR studies of some naturally occurring amentoflavone and hinokiflavone bioflavonoids. Phytochemstry 1987, 26, 3335-3337. [CrossRef]

38. Fonseca, F.N.; Ferreira, A.J.S.; Sartorelli, P.; Lopes, N.P.; Floh, E.I.S.; Handro, W.; Kato, M.J. Phenylpropanoid derivatives and biflavones at different stages of differentiation and development of Araucaria angustifolia. Phytochemistry 2000, 55, 575-580. [CrossRef]

39. Nono, R.N.; Barboni, L.; Teponno, R.B.; Quassinti, L.; Bramucci, M.; Vitali, L.A.; Petrelli, D.; Lupidi, G.; Tapondjou, A.L. Antimicrobial, antioxidant, anti-inflammatory activities and phytoconstituents of extracts from the roots of Dissotis thollonii Cogn.(Melastomataceae). S. Afr. J. Bot. 2014, 93, 19-26. [CrossRef]

40. Shaheen, F.; Muhanmmad, A.; Rubeena, S.; Irfanullah; Sarah, B. Spectral assignments and reference data. Magn. Reson. Chem. 2001, 39, 399-405.

41. Moujir, L.M.; Seca, A.M.L.; Araujo, L.; Silva, A.M.S.; Barreto, M.C. A new natural spiro heterocyclic compound and the cytotoxic activity of the secondary metabolites from Juniperus brevifolia leaves. Fitoterapia 2011, 82, 225-229. [CrossRef] [PubMed]

42. Lee, S.A.G.; Liliana, A.B.G.; Miguel, A.G. Anti HHV-1 and HHV-2 activity in vitro of abietic and dehydroabietic acid derivatives. Pharmacologyonline 2012, 1, 36-42.

43. Muhammad, A.; Azhar, R.; Ghulam, H.; Muhammad, A.S.; Muhammad, K.Z.; Haseeb, A.; Iqra, S.; Ammara, R.; Maleeha, M.; Sevki, A.; et al. Ginkgetin: A natural biflavone with versatile pharmacological activities. Food. Chem. Toxicol. 2020, 145, 111642.

44. Ye, Z.N.; Yu, M.Y.; Kong, L.M.; Wang, W.H.; Yang, Y.F.; Liu, J.Q.; Qiu, M.H.; Li, Y. Biflavone ginkgetin, a novel wnt inhibitor, suppresses the growth of medulloblastoma. Nat. Prod. Bioprospect. 2015, 5, 91-97. [CrossRef] [PubMed]

45. Sasaki, H.; Kitoh, Y.; Tsukada, M.; Miki, K.; Koyama, K.; Juliawaty, L.D.; Hakim, E.H.; Takahashi, K.; Kinoshita, K. Inhibitory activities of bioflavonoids against amyloid-b peptide 42 cytotoxicity in PC-12 cells. Bioorganic Med. Chem. Lett. 2015, 25, 2831-2833. [CrossRef] [PubMed] 